\title{
Aplikasi Virtual Reality Media Pembelajaran Sistem Tata Surya
}

\author{
I Putu Astya Prayudha, A.A. Kt. Agung Cahyawan Wiranatha, I Made Sunia Raharja \\ Program Studi Teknologi Informasi Universitas Udayana \\ Bukit Jimbaran, Bali, Indonesia, telp. (0361) 701806 \\ e-mail: astyaprayudha1@gmail.com, agung.cahyawan@unud.ac.id, sunia.raharja@gmail.com
}

\begin{abstract}
Abstrak
Pembelajaran sistem tata surya diajarkan sejak sekolah dasar. Materi pembelajaran sistem tata surya umumnya dijelaskan melalui papan tulis dan menggunakan buku, hal ini menyebabkan kurangnya visualisasi tentang sistem tata surya yang menjadi kendala dalam proses pembelajaran sistem tata surya. Pengembangan Aplikasi Virtual Reality Media Pembelajaran Sistem Tata Surya pada penelitian ini bertujuan mempermudah pembelajaran dengan penambahan visualisasi penyampaian materi terkait sistem tata surya. Aplikasi dirancang menggabungkan hiburan dan pengetahuan dimana pengguna berinteraksi dengan lingkungan virtual dan melihat keberadaan dari planet beserta informasi planet yang ada didalam sistem tata surya secara virtual. Aplikasi dikembangkan dengan penyampaian pembelajaran berupa teks dan suara untuk memberikan pengetahuan kepada pengguna seperti jarak planet terhadap Matahari, diameter, lapisan, dan kandungan penyusun planet. Pengguna setuju terhadap Aplikasi Virtual Reality Media Pembelajaran Sistem Tata Surya efektif mempermudah pembelajaran terkait sistem tata surya yang dibuktikan dari hasil kuesioner yaitu sebesar $60 \%$ untuk nilai setuju pada aspek konten.
\end{abstract}

Kata Kunci : Virtual Reality, Sistem Tata Surya, Pembelajaran, Android

\begin{abstract}
Learning of the solar system is taught since primary school. The learning materials of the solar system are generally explained through blackboards and using books, causing a less of visualization of the solar system that becomes an obstacle in the learning process of the solar system. Develop Virtual Reality Application Learning Media of Solar System in this study aims to facilitate learning with the addition of visualization of the delivery of materials related to the solar system. The application is designed to combine entertainment and knowledge where users interact with virtual environments and see the existence of planets and planets information in the solar system with virtually mode. Application are developed with the delivery of text and voice learning to provide knowledge to users such as the distance the planet to the Sun, diameter, layers, and the constituents of the planet. Users agree Virtual Reality Application Learning Media of Solar System effectively facilitate learning related to the solar system system as evidenced by the questionnaire of $60 \%$ for agree value on the content aspect.
\end{abstract}

Keywords : Virtual Reality, Solar System, Learning, Android

\section{Pendahuluan}

Pembelajaran sistem tata surya diajarkan sejak sekolah dasar [1]. Materi pembelajaran sistem tata surya umumnya dijelaskan melalui papan tulis dan menggunakan buku, hal ini menyebabkan kurangnya visualisasi tentang sistem tata surya yang menjadi kendala dalam proses pembelajaran sistem tata surya [2]. Siswa lebih tertarik pembelajaran sistem tata surya menggunakan cara yang lebih menarik contohnya disertai alat peraga dan pembelajaran berbasis aplikasi, seperti siswa kelas 6 SD Sukabirus, sebanyak 75\% siswa lebih tertarik pengenalan sistem tata surya berbasis aplikasi [3].

Pengembangan Aplikasi Virtual Reality Media Pembelajaran Sistem Tata Surya pada penelitian ini bertujuan mempermudah pembelajaran dengan penambahan visualisasi penyampaian materi terkait sistem tata surya. Aplikasi dirancang dengan menggabungkan 
hiburan dan pengetahuan yaitu pengguna berinteraksi dengan lingkungan virtual dan melihat keberadaan dari planet beserta informasi planet. Aplikasi dikembangkan dengan penyampaian pembelajaran berupa teks dan suara untuk memberikan pengetahuan kepada pengguna seperti jarak planet terhadap Matahari, diameter, lapisan, dan kandungan penyusun planet. Aplikasi Virtual Reality Media Pembelajaran Sistem Tata Surya diharapkan dapat mempermudah pembelajaran terkait sistem tata surya.

\section{Metodologi Penelitian}

Penelitian ini menggunakan metode prototype yaitu pengguna dapat melihat pembuatan model sistem dari tampilan yang dibuat [4]. Alur metode prototype terdiri dari lima tahapan diantaranya yaitu tahap identifikasi kebutuhan, mengembangkan prototype, koding aplikasi, pengujian aplikasi, dan implementasi. Identifikasi kebutuhan dilakukan untuk mengetahui kebutuhan pengguna yaitu pengguna membutuhkan sarana visualisasi dalam mendukung pembelajaran sistem tata surya. Tahap mengembangkan prototype yaitu membuat gambaran umum dari aplikasi yang dikembangkan. Tahap selanjutnya setelah pengguna setuju dengan prototype yang telah dibuat maka dilanjutkan ke tahap koding aplikasi yaitu mengembangkan prototype yang dibuat sebelumnya menjadi sebuah aplikasi dengan bantuan software 3DS Max dan Unity. 3DS Max digunakan untuk membuat model 3D dari objek yang ada dalam aplikasi sedangkan Unity digunakan untuk koding aplikasi menggunakan bahasa C\# dan Javascript. Tahap keempat yaitu pengujian aplikasi yang dilakukan kepada pengguna untuk mengetahui aplikasi dapat memberikan visualisasi dan mendukung pembelajaran sistem tata surya. Tahap kelima yaitu implementasi yang diterapkan kepada pelajar untuk memberikan pengetahuan dan dapat mempermudah pembelajaran terkait sistem tata surya melalui Aplikasi Virtual Reality Media Pembelajaran Sistem Tata Surya.

\subsection{Gambaran Umum Aplikasi}

Gambaran umum dari Aplikasi Virtual Reality Media Pembelajaran Sistem Tata Surya yang dikembangkan dijelaskan pada Gambar 1.

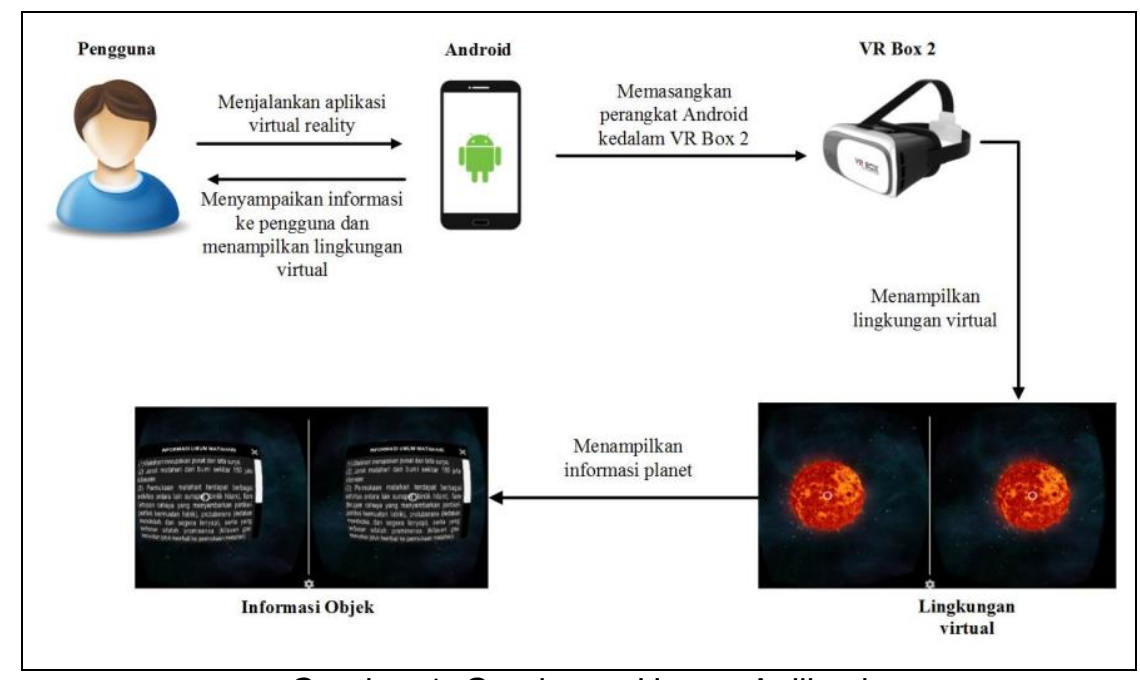

Gambar 1. Gambaran Umum Aplikasi

Tahapan awal kerja dari aplikasi yaitu pengguna menjalankan aplikasi pada perangkat Android, kemudian perangkat Android dipasangkan kedalam VR Box 2 untuk menghubungkan pengguna dengan lingkungan virtual dari Aplikasi Virtual Reality Media Pembelajaran Sistem Tata Surya. Pengguna dapat berinteraksi dengan lingkungan virtual berupa sistem tata surya dan melihat informasi objek yang ada didalam sistem tata surya. Informasi atau pengetahuan yang diberikan kepada pengguna disampaikan dalam bentuk teks dan suara seperti jarak planet terhadap Matahari, diameter, lapisan, dan kandungan penyusun planet. Fitur quiz terdapat dalam aplikasi yang digunakan untuk mengetahui tingkat pemahaman dari pengguna setelah mendapatkan informasi dari setiap objek didalam aplikasi. 


\section{Kajian Pustaka}

Kajian Pustaka merupakan bahan yang dijadikan sebagai acuan dalam pembuatan penelitian yang terdiri dari State of the Art, Virtual Reality, Sistem Tata Surya, dan Unity 3D.

\subsection{State of the Art}

Beberapa penelitian terdahulu terkait media pembelajaran diantaranya Penelitian berjudul "Aplikasi Augmented Reality Magic Book Pengenalan Binatang untuk Siswa TK", "Game Edukasi Mengenal Huruf Katakana dan Hiragana Berbasis Android", dan "Instructional Learning Media to Create Upakara for Nyiramin Layon Procession based on Android". Penelitian yang berjudul "Aplikasi Augmented Reality Magic Book Pengenalan Binatang untuk Siswa TK" oleh I Dewa Gede Wahya Dhiyatmika tahun 2015, mengembangkan aplikasi pembelajaran pada perangkat Android. Aplikasi dibuat untuk menarik minat anak dalam mengenal jenis-jenis binatang. Aplikasi ditampilkan dalam bentuk augmented reality menggunakan marker berupa objek 3 dimensi binatang, suara dan informasi dari binatang. Pengenalan jenis-jenis binatang menjadi lebih menarik karena penyajian aplikasi lebih inovatif menggunakan smartphone [5].

Penelitian "Game Edukasi Mengenal Huruf Katakana dan Hiragana Berbasis Android" yang dibuat oleh Agus Gede Adi Prayoga tahun 2015 merupakan game edukasi yang bertujuan mengatasi kesulitan pembelajaran terkait bahasa Jepang yaitu penguasaan huruf Katakana dan Hiragana. Materi aplikasi bersumber dari kurikulum Ni Hon Go No Kyoukasho dan Ni Hon Go 1. Aplikasi memiliki tiga fitur pembelajaran yaitu tabel, menulis dan tebak huruf serta fitur permainan [6].

Penelitian dengan judul "Instructional Learning Media to Create Upakara for Nyiramin Layon Procession based on Android" yang dibuat oleh A. A. K. Oka Sudana tahun 2016 membahas aplikasi media pembelajaran pembuatan Upakara atau Eteh-eteh yang ditampilkan dalam bentuk augmented reality. Upakara atau Eteh-eteh merupakan perlengkapan yang digunakan untuk memandikan mayat pada upacara kremasi umat Hindu atau disebut dengan Nyiramin Layon. Aplikasi dibuat karena informasi tentang Upakara atau Eteh-eteh sangat terbatas dan proses pembuatan yang rumit sehingga dibuatkan media pembelajaran dalam bentuk aplikasi augmented reality. Keunggulan media pembelajaran pembuatan Upakara atau Eteh-eteh yaitu menggunakan objek tiga dimensi, foto dan video tentang pembuatan Upakara atau Eteh-eteh [7].

Aplikasi Virtual Reality Media Pembelajaran Sistem Tata Surya sama halnya dengan penelitian terdahulu yang telah dijelaskan, dikembangkan berfungsi sebagai media pembelajaran, tetapi pembelajaran yang disampaikan terkait sistem tata surya.

\subsection{Virtual Reality}

Virtual reality adalah teknologi yang menciptakan lingkungan secara virtual. Interaksi pada aplikasi virtual reality menggunakan sensor Accelerometer dan Gyroscope pada perangkat [8]. Virtual reality merupakan teknologi memungkinkan pengguna dapat berinteraksi pada lingkungan yang disimulasikan oleh komputer (computer-simulated environment). Lingkungan virtual dalam bentuk audio dan grafis. Lingkungan virtual tersebut membuat pengguna seperti berada pada dunia nyata [9].

\subsection{Sistem Tata Surya}

Sistem tata surya merupakan benda langit yang terdiri dari Matahari dan objek yang terikat oleh gaya gravitasi Matahari.Objek-objek tersebut terdiri dari delapan planet dengan orbit berbentuk elips. Planet didalam sistem tata surya yaitu planet Merkurius, Venus, Bumi. Mars, Jupiter, Saturnus, Uranus, Neptunus. Tata surya yang terdiri dari Matahari, planet-planet, satelitsatelit, komet, meteor, dan asteroid merupakan sejumlah bintang yang bergabung di dalam kelompok yang dikenal sebagai galaksi [10].

\subsection{Unity 3D}

Unity 3D merupakan tools yang digunakan dalam membuat objek 3D. Bahasa pemrograman yang digunakan yaitu $\mathrm{C \#}$, javascript, dan boo. Unity 3D dapat berjalan pada Windows, Mac, Xbox 360, Playstation 3, Wii, iPad, iPhone, serta Android [11]. Penggunaan Unity 3D dalam pembuatan aplikasi Android salah satunya digunakan pada aplikasi "Learning Media of Balinese Script Writing Based on Augmented Reality" yang dikembangkan oleh A. A. K. Oka Sudana tahun 2016 [12]. 


\section{Hasil dan Pembahasan}

Hasil dan pembahasan membahas mengenai tampilan dari aplikasi yang telah diuji coba dan analisa hasil kuesioner sebagai sarana untuk mengetahui tingkat kesesuaian aplikasi yang dibuat, beserta hasil penilaian quiz yang dicoba oleh pengguna.

4.1. Hasil Tampilan Aplikasi

Aplikasi Virtual Reality Media Pembelajaran Sistem Tata Surya memiliki dua scene sebagai lingkungan virtual yaitu Scene Menu Awal dan Scene Luar Angkasa. Scene Menu Awal memuat informasi penggunaan dari Aplikasi Virtual Reality Media Pembelajaran Sistem Tata Surya, sedangkan Scene Luar Angkasa memuat lingkungan sistem tata surya dimana terdapat objek Matahari, planet dan lainnya.

\section{Scene Menu Awal}

Scene Menu Awal tampil terlebih dahulu ketika pengguna baru menjalankan aplikasi. Scene Menu Awal digunakan untuk memberikan informasi mengenai cara penggunaan aplikasi sehingga pengguna lebih mudah dalam mempelajari sistem tata surya. Gambar 2 merupakan tampilan dari Scene Menu Awal.

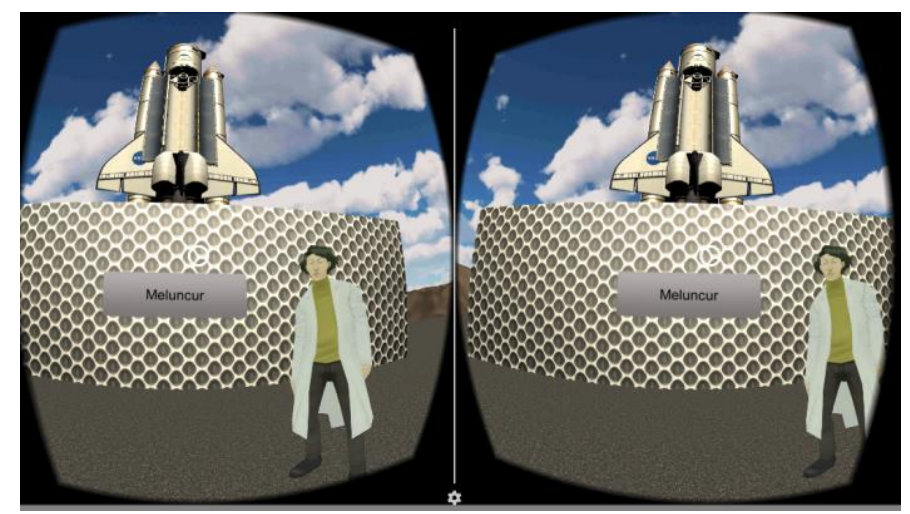

Gambar 2. Tampilan Scene Menu Awal

Pengguna melihat karakter seorang profesor sebagai pemberi informasi mengenai penggunaan aplikasi. Pengguna hanya perlu mengarahkan cursor yang ada ditengah layar ke arah karakter dan melakukan click pada karakter maka karakter memberikan informasi mengenai penggunaan aplikasi. Pengguna dapat berpindah ke Scene Luar Angkasa dengan cara memilih Button Meluncur.

\section{Scene Luar Angkasa}

Objek seperti Matahari, planet, komet dan objek lainnya terdapat pada Scene Luar Angkasa. Gambar 3 merupakan tampilan dari Scene Luar Angkasa yang terdapat objek-objek seperti Matahari, planet dan lainnya. Pengguna dapat melihat informasi dari objek, dengan memilih atau mendekati objek tersebut.

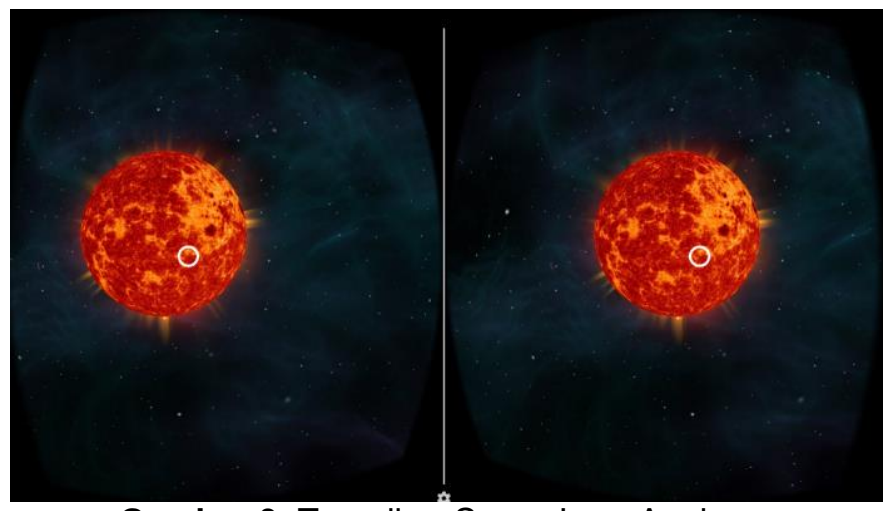

Gambar 3. Tampilan Scene Luar Angkasa 
3. Menu Objek

Menu dari objek muncul saat pengguna telah sampai dan berhenti di depan objek yang dituju, seperti contoh pada Gambar 4 yaitu menu dari objek Merkurius secara otomatis muncul ketika pengguna telah sampai atau berada di depan objek planet Merkurius. Menu dari objek planet memuat informasi diantaranya informasi umum, lapisan planet, uji pengetahuan dan keluar.

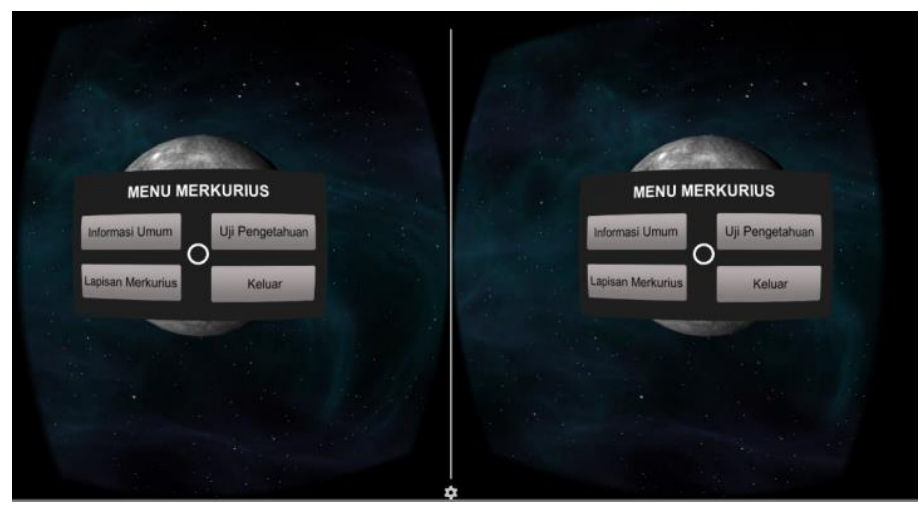

Gambar 4. Menu Merkurius

4. Informasi Umum Objek

Informasi umum yang diberikan berupa informasi dari planet seperti diameter, jarak terhadap Matahari, jumlah satelit dan lainnya. Gambar 5 merupakan contoh informasi umum dari planet Merkurius. Informasi umum yang diberikan bukan hanya melalui teks tetapi juga dapat didengar melalui suara yang dapat diakses dengan memilih Button Suara pada bagian pojok kiri atas informasi umum. Pengguna dapat kembali ke menu planet dengan cara memilih Button Keluar.

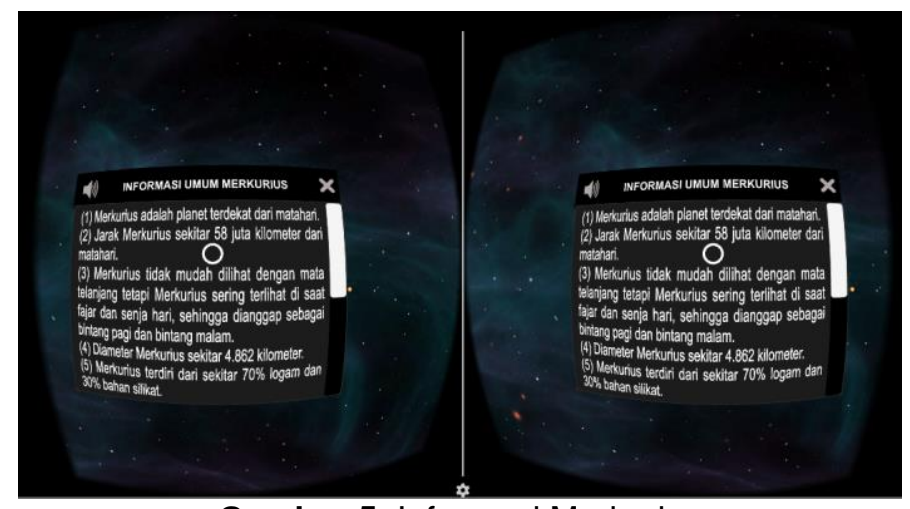

Gambar 5. Informasi Merkurius

5. Informasi Lapisan Planet

Informasi yang disediakan aplikasi bukan hanya informasi umum tetapi juga informasi lapisan planet. Tampilan dari informasi lapisan planet dapat dilihat dengan cara memilih Button Lapisan Planet pada menu planet. Gambar 6 merupakan tampilan dari lapisan Merkurius ketika pengguna memilih Button Lapisan Merkurius pada menu objek Merkurius. Objek planet Merkurius berubah menjadi beberapa lapisan dimana terdapat keterangan dari tiap lapisan. Button Keterangan Lapisan digunakan untuk melihat keterangan lebih lengkap dari lapisan. 


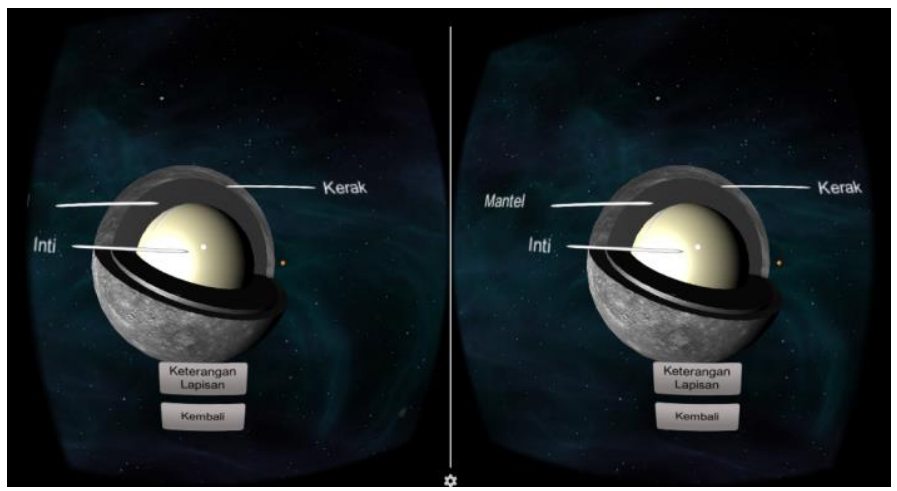

Gambar 6. Lapisan Planet

6. Uji Pemahaman

Informasi yang diberikan kepada pengguna dapat diuji pada fitur quiz dengan cara memilih Button Uji Pemahaman pada menu planet. Gambar 7 merupakan tampilan dari quiz Merkurius. Quiz yang terdapat pada setiap planet dapat menguji tingkat pemahaman dari pengguna. Soal dari tiap planet berjumlah lima soal dimana masing-masing soal bernilai 20 . Pengguna harus memilih jawaban yang dianggap benar dan hasil nilai akhir muncul setelah pengguna selesai menjawab kelima soal yang ada.

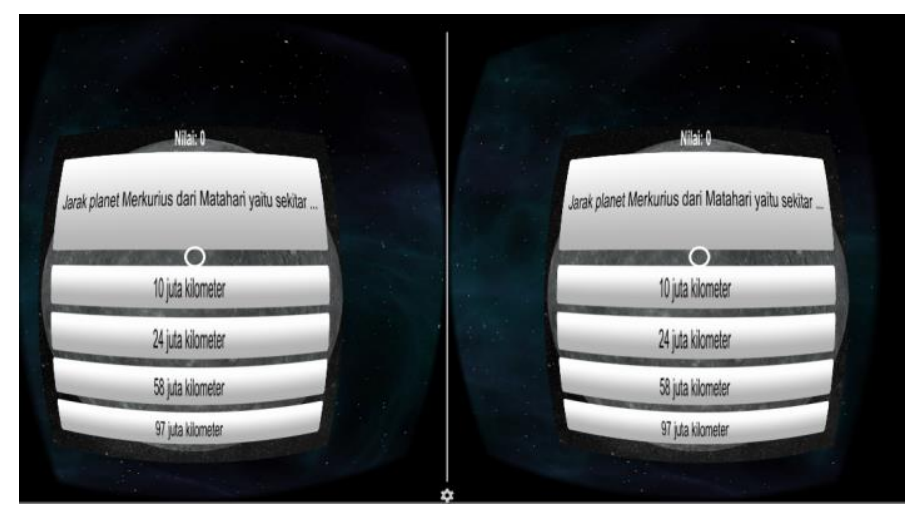

Gambar 7. Quiz Planet

\subsection{Pengujian Kesesuaian Aplikasi}

Kesesuaian aplikasi diuji menggunakan kuesioner yang diberikan kepada 15 responden. Kuesioner menggunakan Skala Likert yang dirancang untuk mengukur sikap yang diterima dari responden dan kemudian divalidasi. Tujuan dari Skala Likert adalah untuk memahami tentang pendapat atau persepsi responden terkait dengan variabel dalam sebuah kuesioner [13]. Pengujian menggunakan 5 kategori jawaban yaitu sangat setuju, setuju, cukup, tidak setuju, sangat tidak setuju. Perhitungan dilakukan berdasarkan aspek dari aplikasi.

1. Aspek Rekayasa Perangkat Lunak

Aspek rekayasa perangkat lunak yaitu kinerja aplikasi yang digunakan pengguna. Hasil dari aspek rekayasa perangkat lunak dapat dilihat pada Gambar 8. 


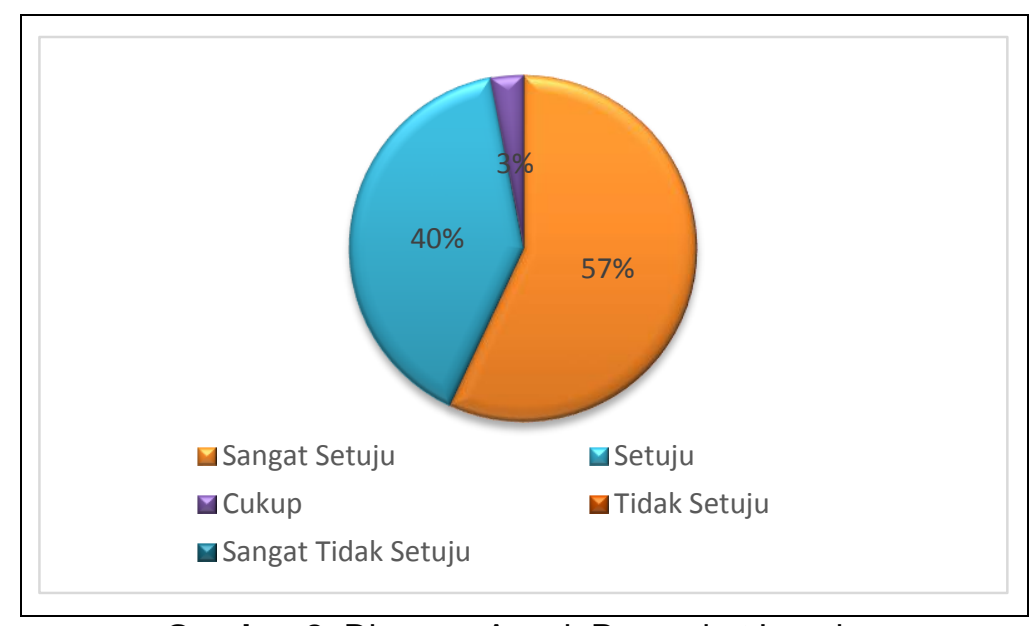

Gambar 8. Diagram Aspek Perangkat Lunak

Gambar 8 menunjukkan bahwa responden pada aspek perangkat lunak menyatakan sangat setuju sebesar $57 \%$, setuju sebesar $40 \%$, cukup sebesar $3 \%$ dan sisanya sebesar $0 \%$. Hasil kuesioner pada aspek perangkat lunak menunjukkan user interface termasuk lingkungan virtual, objek, dan informasi telah sesuai dengan tujuan pengembangan aplikasi dan mudah dipahami.

2. Aspek Entertainment atau Hiburan

Aspek entertainment atau hiburan yaitu penilaian yang didapat dari pengguna, dari sisi hiburan. Gambar 9 menunjukkan bahwa responden pada aspek entertainment atau hiburan menyatakan sangat setuju sebesar $42 \%$, setuju sebesar $47 \%$, cukup sebesar $11 \%$ dan sisanya sebesar $0 \%$. Hasil kuesioner pada aspek entertainment atau hiburan menunjukkan Aplikasi Virtual Reality Media Pembelajaran Sistem Tata Surya memberikan hiburan kepada pengguna.

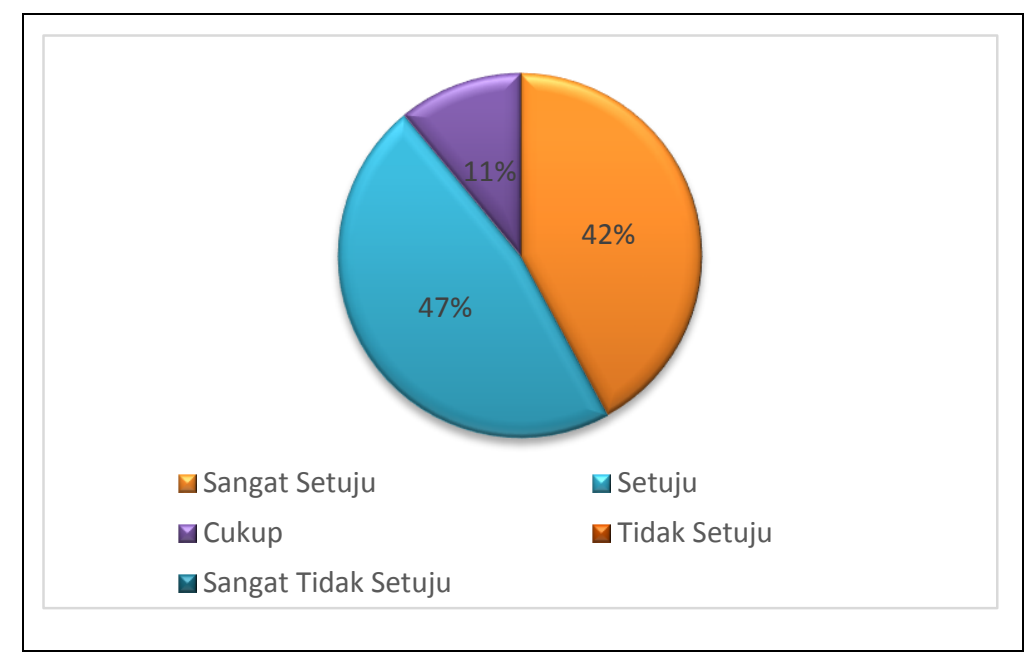

Gambar 9. Diagram Aspek Entertainment

3. Aspek Konten

Aspek konten yaitu penilaian terhadap informasi dan edukasi yang dapat diberikan kepada pengguna. Hasil dari aspek konten dapat dilihat pada Gambar 10. 


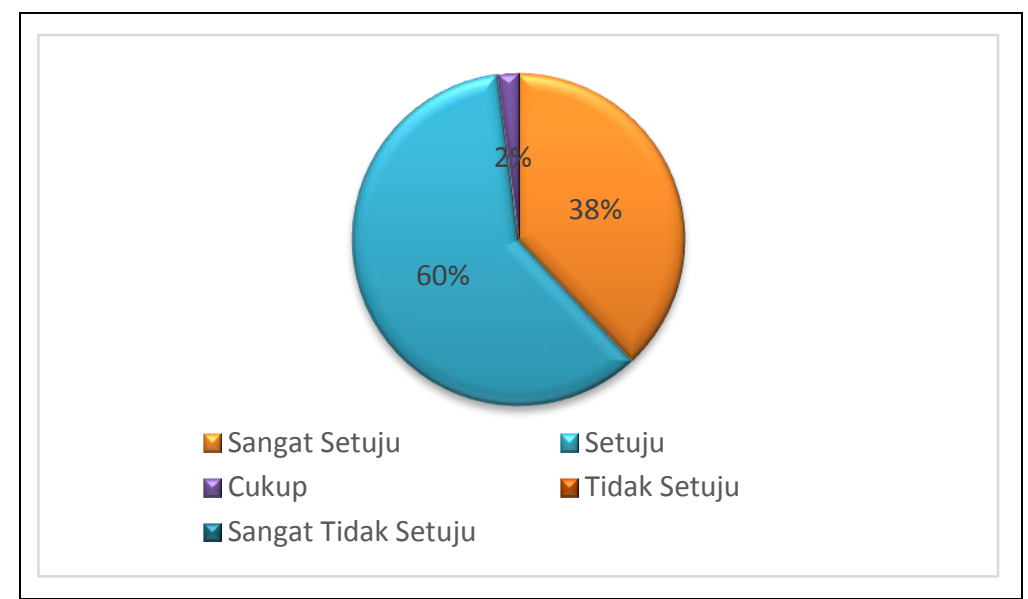

Gambar 10. Diagram Aspek Konten

Gambar 10 menunjukkan bahwa responden pada aspek konten menyatakan sangat setuju sebesar $38 \%$, setuju sebesar $60 \%$, cukup sebesar $2 \%$ dan sisanya sebesar $0 \%$. Hasil kuesioner pada aspek konten menunjukkan Aplikasi Virtual Reality Media Pembelajaran Sistem Tata Surya mempermudah pembelajaran terkait sistem tata surya.

\subsection{Pengujian Pengetahuan Pengguna}

Pengujian selanjutnya yaitu pengujian terhadap sejauh mana informasi yang telah didapatkan pengguna dengan menguji tingkat pemahaman pada fitur quiz. Tabel 1 dan Tabel 2 menunjukkan bahwa nilai rata-rata pengguna setelah menjawab soal dari quiz tiap planet yaitu diatas 75. Hasil pengujian pengetahuan menunjukkan pengguna telah mampu menerima informasi dari aplikasi dan aplikasi yang dibuat telah mampu memberikan pengetahuan bagi pengguna.

Tabel 1. Daftar Nilai Quiz 1

\begin{tabular}{cc}
\hline Pengguna & Nilai \\
\hline 1 & 82 \\
2 & 84 \\
3 & 86 \\
4 & 84 \\
5 & 88 \\
6 & 72 \\
7 & 92 \\
8 & 72 \\
9 & 84 \\
10 & 76 \\
11 & 80 \\
12 & 90 \\
13 & 76 \\
14 & 86 \\
15 & 84 \\
\hline
\end{tabular}

Tabel 2. Daftar Nilai Quiz 2

\begin{tabular}{cc}
\hline Pengguna & Nilai \\
\hline 16 & 78 \\
17 & 84 \\
18 & 88 \\
19 & 84 \\
20 & 84 \\
21 & 84 \\
22 & 82 \\
23 & 82 \\
24 & 82 \\
25 & 80 \\
26 & 74 \\
27 & 88 \\
28 & 84 \\
29 & 84 \\
30 & 84 \\
\hline
\end{tabular}

\section{Kesimpulan}

Aplikasi Virtual Reality Media Pembelajaran Sistem Tata Surya yang dihasilkan mampu mempermudah proses pembelajaran terkait sistem tata surya. Pengguna setuju terhadap Aplikasi Virtual Reality Media Pembelajaran Sistem Tata Surya efektif mempermudah pembelajaran terkait sistem tata surya yang dibuktikan dari hasil kuesioner yaitu sebesar $60 \%$ untuk nilai setuju pada aspek konten. Hasil kuesioner aspek konten yang diperoleh didukung dengan uji coba pemahaman yang terdapat didalam aplikasi, dimana 27 dari 30 pengguna dapat menjawab pertanyaan dengan nilai diatas 75 . 


\section{Daftar Pustaka}

[1] Endang Retnoningsih, "Metode Pembelajaran Pengenalan Tata Surya pada Sekolah Dasar Berbasis Computer Based Instruction (CBI)," Blina Insani ICT Jurnal, vol. 3, no. 1, pp. 194-204, 2016.

[2] T. A. Ananda, N. Safriadi, A. S. Sukamto, "Penerapan Augmented Reality sebagai PlanetPlanet di Tata Surya," Jurnal Sistem dan Teknologi Informasi (JUSTIN), vol. 1, no. 1, 2015.

[3] Yuni Sartika, T. D. Tambunan, P. A. Telnoni, "Aplikasi Pembelajaran Tata Surya untuk IPA Kelas 6 Sekolah Dasar Menggunakan Augmented Reality Berbasis Android," eProceeding of Applied Science, 2016, pp. 895-908.

[4] D. Rosmala, M. D. Djatmiko, B. Julianto, "Implementasi Aplikasi Website E-Commerce Batik Sunda dengan menggunakan Protokol SSL," Jurnal Informatika. ITENAS Bandung, vol. 3, no. 3, pp. 58-67, 2012.

[5] I. D. Gede, W. Dhiyatmika, I K. Gede Darma Putra, Ni Made Ika Marini, "Aplikasi Augmented Reality Magic Book Pengenalan Binatang untuk Siswa TK," Lontar Komputer, vol. 6, no. 2, pp. 589-596, 2015.

[6] A. Gede, A. Prayoga, I. P. A. Bayupati, A.A. Kt. Agung Cahyawan Wiranatha, "Game Edukasi Mengenal Huruf Katakana dan Hiragana Berbasis Android," Lontar Komputer, vol. 6, no. 3, pp. 621-633, 2015.

[7] A. A. K. Oka Sudana, R. R. S. Sarah Wulan Ayu, Ni Kadek Ayu Wirdiani, "Instructional Learning Media to Create Upakara for Nyiramin Layon Procession based on Android," International Journal Computer Application, vol. 144, no. 10, pp. 32-35, 2016.

[8] S. Gde, A. Bhaskara, P. W. Buana, and I. K. A. Purnawan, "Permainan Edukasi Labirin Virtual Reality Dengan Metode Collision Detection Dan Stereoscopic," Lontar Komputer, vol. 8, no. 2, pp. 65-76, 2017.

[9] Y. N. Bahar, "Aplikasi Teknologi Virutal Reality Bagi Pelestarian Bangunan Arsitektur," Jurnal Desain Konstruksi, vol. 13, no. 2, pp. 34-45, 2014.

[10] Sri Melati Sagita, "Pembelajaran Tata Surya Menggunakan Teknologi Augmented Reality," Jurnal Faktor Exacta, vol. 7, no. 3, pp. 224-235, 2014.

[11] B. Sihite, F. Samopa, and N. A. Sani, "Pembuatan Aplikasi 3D Viewer Mobile dengan Menggunakan Teknologi Virtual Reality (Studi Kasus: Perobekan Bendera Belanda di Hotel Majapahit)," Teknik Pomits, vol. 2, no. 2, pp. 397-400, 2013.

[12] A. A. K. Oka Sudana, K. Suar Wibawa, I. M. A. Dhanu Tirtha, "Learning Media of Balinese Script Writing Based on Augmented Reality," Journal of Theoretical and Applied Information Technology, vol. 90, no. 1, pp. 31-39, 2016.

[13] A. Joshi, S. Kale, S. Chandel, D. Pal, "Likert Scale: Explored and Explained," British Journal of Applied Science \& Technology, vol. 7, no. 4, pp. 396-403, 2015. 